\title{
Bilingualism in the West Bank: The Impact of Hebrew on Arabic under the Israeli Occupation Since 1967
}

\author{
Oqab Jabali ${ }^{*}$, Abed Alkarim Ayyoub ${ }^{2}$ \\ ${ }^{I}$ Language Center, Faculty of Humanities, An-Najah National University, Nablus, Palestine \\ ${ }^{2}$ Faculty of Economics and Social Studies, An-Najah National University, Nablus, Palestine
}

*Corresponding Author: Oqab Jabali, Language Center, Faculty of Humanities, An-Najah National University, Nablus, Palestine

\begin{abstract}
Arabic has been facing different challenges in the West Bank since its occupation in 1967 by the Israelis who sought to obliterate the Arab identity of the Palestinians to build a Jewish entity that realizes the dreams of the Jews and crumbles the Palestinian unity. Arabic has been among the causalities of the Israeli occupation via Hebrew that strived to negatively impact it. The current investigative study sought to trace the effect of occupation on bilingualism and identify the reality of Arabic under the Israeli occupation. The researchers tried to explore the role of Palestinian institutions in preserving the Arabic language and resisting linguistic invasion that may result in unwanted bilingualism. The researchers also tried to identify the various aspects of linguistic invasion, linguistic normalization, bilingualism in the West Bank and the value of Hebrew and whether the Israeli occupation will succeed in its endeavors. The study findings showed that Hebrew has impacted Arabic negatively when its words leaked to Arabic. This leakage is a matter of intrusion and will not result in a deterioration of Arabic nor a replacement of it by Hebrew as Palestinians believe that language maintenance is associated with identity and culture preservation.
\end{abstract}

Keywords: Arabic; bilingualism; Hebrew; Israeli occupation; West Bank.

\section{INTRODUCTION}

It has been argued that the Arabic Language has been honored and respected by the Almighty God when He preferred it over all other languages when He revealed the Holy Quran in it. This revelation has doubtfully helped in the preservation of the language against change, misuse and, on top of all, against futility of abusers.

Languages play significant roles in the building of societies and the construction of personal, independent identities of individuals and nations, as well. Previous literature has proved that a language is considered as an essential constituent in individual identities and collective identities as well; it is also a significant factor that has plays a fundamentally crucial role in all political, social and cultural interactions (Harel-Schlef, 2012). A language is very likely to affect the way a whole society thinks to the extent that political awareness and national consciousness are hardly attainable unless they go hand in hand with sound, conscious linguistic awareness (Mubarak, 1979).

The Arabic language is constantly facing different challenges which increase by time. It is, no doubt, witnessing a state of cultural alienation in light of fierce competition to the extent that Arabic seems to be incapable of achieving a strong, influential presence and impact due to the fact that Arabs other language users cannot assert themselves these days. Perhaps the globalization of linguistic culture is one of the biggest challenges facing the Arabic language. This globalization seeks to impose the most powerful language on human societies whose cultural, political and economic defensive measures and means are incapable of confronting this linguistic fierce attack that threatens the cultural foundations and the characteristic features of civilization. Consequently, globalization has started to sweep the linguistic, and cultural specificities, of a society, which form the hard core of national existence. This encouraged most European peoples or nations, represented by the French, to call for unity against US imperialism and cultural invasion and getting rid of the brunt of the English language (Khoury, 2005).

Another significant challenge that faces Arabic is, of course, the Israeli occupation or colonization. Israel occupied part of Palestine in 1948, and completed the occupation of the rest of the Palestinian 
territories, called West Bank and Gaza Strip, in 1967. Israel has sought, since then until the present time, to work to blur and/or harm everything related to Arab identity of the Palestinians in order to build a Jewish, strong entity to shelter the Jews, achieve their aspirations, realizes their dreams and weaken or crumble the Palestinian unity.

The Israeli occupation of Palestine has resulted in tremendous repercussions and offsets that still affect the various aspects of the Palestinian people which lived and is still living under a nasty, colonial occupation. It has also resulted in a multiplicity of negative impacts that changed almost everything related to the Palestinian society. It is taken for granted that the effects of such a change vary in intensity.

One of the most significant aspects of the Palestinian society that has been negatively impacted by the Israeli occupation is, of course, the language. For any society, the language as a key marker of national or ethnic identity (Suleiman, 2004). Arabic is, surely, the official, national language of Palestine; it is one of the most important pillars of the Palestinian identity. The Israeli occupation tries constantly to suppress Arabic though Hebrew; the Israelis tried to obscure the Arabic language or even replace it with Hebrew, but they failed.

There is plenty of research about the reality of the Arabic language and the impact of Hebrew on it in the Green line area, i.e. the part of Palestine which was occupied in 1948. Some researchers have studied the position of Arabic in that area (e.g., Koplewitz, 1990; Harel-Schlef, 2005; Abu Al-Rob, 2011; Amara, 2013; Nashef, 2018) while others have investigated the impact of Hebrew on Arabic from different perspectives (e.g., Odeh, 2015; Zidan, 2010; Jabr \& Hamad, 2009; Kayyal, 2008; AlRifa'ai, 2001).

As far as the reality of Arabic in the West Bank is concerned, no literature has been identified by the researchers. Consequently, the current study sought to thoroughly investigate the reality of bilingualism and the Arabic language in the West Bank focusing on the impact of Hebrew on Arabic and whether this impact is positive and/or negative. The researchers meant to answer the following questions:

First: What is the role of Palestinian institutions in preserving Arabic and resisting linguistic invasion which is exerted and practiced by the language of the Israeli occupier?

Second: What are the manifestations of the linguistic invasion which Arabic faces in the occupied West Bank?

Third: Do the Palestinians in the West Bank face the problem of linguistic dualism: Arabic and Hebrew?

Fourth: Is there any linguistic normalization? If yes, do the Palestinians tend to resist it or manifest linguistic tolerance?

Fifth: Is the Hebrew language considered a spoil of occupation, or does it reveal a defect, which might threaten the Arabic language?

\section{THE LINGUISTIC INVASION EXERTED BY THE LANGUAGE OF THE ISRAELI OCCUPIER AND THE ROLE OF PALESTINIAN INSTITUTIONS IN PRESERVING THE ARABIC LANGUAGE}

It is known that the language, whatever it is, of any nation is, no doubt, influenced by historical events that may leave their marks on it and result in certain manifestations including, for example, new coinages, new meanings and, sometimes, Arabizations. The invasion and occupation of a country is considered as one of the most prominent events that may lead to creating a new linguistic reality on the ground that entails preserving the language and calls for the protection of it from collapse. Such a reality is very likely to have visible manifestations in languages which do not have glorious past or those which have not recorded a high, noble linguistic legacy or linguistic heritage. Realities, like these, mostly affect humble, submissive languages that have only spoken, unrecorded dialects or languages that are challenged by local dialects within the same boundaries. Arabic, in occupied Palestine, does not belong to this last category of languages; it has glorious, noble past, legacy, thought and civilization undaunted or deterred by the Israeli occupation. It has survived in the face of, Hebrew, the language of the occupier. However, this does not mean that Hebrew has not impacted the Palestinian Arabic; the effect of Hebrew is not detrimental to Arabic (Jabr, 1990). 
Perhaps what enabled Arabic to stand firmly in front of occupation and preserve the Palestinian linguistic heritage and culture is the practices of the Israeli occupier themselves; they did not exert any dangerous actions against Arabic as they recognize it as an official language just like Hebrew. Israel has not issued any law that clearly states, in its final form, what the official languages of the country are. Paragraph (82) of "Palestine Order in Council" of the High issued on August 14, 1922, for the British Mandate of Palestine states that Palestine/Israel would have three official languages: English, Arabic and Hebrew (Malka, et al., 2016). A political fundamental amendment was enforced to this paragraph on May 19, 1948 when the Israeli Knesset published the provisional legislative branch. Based on amendment (Paragraph 15-b) English as an official language is abolished; Hebrew has become the national language of the state of Israel and Arabic has become just another minority language (Spolsky and Shohamy, 1999). Israel could not abolish the official status of the Arabic language due to pragmatic motives and International considerations (Harel-Schlef, 2012).

This somehow aggressive attitude toward Arabic has motivated the role of the Palestinian national institutions in the West Bank before the advent of the Palestinian National authority and even afterwards. They strive to keep Arabic the official language of the country by standing firmly in front of whatever may pose a risk to Arabic. All of these institutions started and develop during the occupation which did not influence their development nor interfere their endeavors to maintain and enrich the language.

The most prominent and influential Palestinian institution that has always been keen on excluding Hebrew from the Palestinian curriculum at any school stage is the Ministry of Education. It has always insisted on the fact that all school subjects at all school levels are to be taught in sound Standard Arabic which is void of any impurity especially if it is introduced by Hebrew. Thankfully, the Palestinian Ministry of Education, represented by eagerly intent and enthusiastic experts, has prepared and introduced complete, integrated curricula that meet the Palestinian aspirations and preserve the legacy and nobility of Arabic. There is no doubt that the Palestinian curricula are good enough to the extent that they are quality curricula as they "ensure inclusive and equitable quality education and promote lifelong learning opportunities for all" (Stabback, 2016, p 4). Moreover, the Ministry of Education spared no effort in producing a curriculum that takes the Palestinian privacy into consideration so that the Palestinian people meet their goals and attain their place among other peoples. It has presented Arabic, to the growing generations of Palestine, as a symbol to the pure Palestinian Arabic identity, on the one hand, and as a means to achieve this identity and preserve it, on the other hand.

Another very significant Palestinian institution is the media whether it is the public or the private and whether it is print Media (Newspapers, Magazines), Broadcast Media (TV, Radio), Outdoor or Out of Home $(\mathrm{OOH})$ Media or the internet. All these types have worked hard to fight against the Israeli linguistic invasion represented by the hegemony of Hebrew when they all use the Arabic language to present their content.

Additionally, there are a lot of universities and community colleges in Palestine that all serve the Arabic language. Most of the use Arabic as a medium for teaching while Hebrew is merely taught as an oriental language in very few departments (mostly the Arabic Department) in these universities following the footsteps of Jordanian and Syrian universities.

Recently, the Palestinian Bayt al-Maqdis Academy of the Arabic Language has been founded to serve Arabic; however, this institution, unlike the stated goal, has not made any significant contribution to resist Hebrew, describe the status quo of Arabic, or clarify the negative impact of Hebrew on Arabic. As a result, all Arabic departments in the Palestinian universities gathered in 2013 to discuss this collapsing Academy.

It is worth mentioning that the Bayt al-Maqdis Academy of the Arabic Language helped three students from An-Najah National University and an administrative assistant Al-Quds Open University supervised by some lexicographers to collect a list of vocabularies in dictionary called "Dictionary of Uprising Glossary"; however, the dictionary is not published yet. Although this compilation is not a true dictionary, it includes two entries that are classified as Hebrew entries. The first word is "Checkpoint or roadblock" which is equivalent to the Arabic word "حاجز =haajiz" and the Hebrew word (מחסום pronounced as mahsoum); the other word is "closure" which is equivalent to the Arabic word (طوق أمني = tawq 'ami) and the Hebrew word (סגר) (Bayt al-Maqdis Academy of the Arabic Language, n.d.). 


\section{ThE MANIFESTATIONS OF THE LINGUISTIC INVASION AGAINST ARABIC IN THE WEST BANK}

Despite the passage of more than fifty years of the occupation of the West Bank, which is sufficient for the Hebrew language to penetrate the Palestinian linguistic performance at both levels: speaking and writing, such a penetration was not widely; its manifestations were so narrow and limited to the extent that it did not cause and harm to the national, Arabic language.

And these manifestations are exposed, in the West Bank, through the following:

A. The names of commercial goods, such as food, beverages, and the like.

B. Transactions and official documents: civil and non-civil.

C. Banners and commercial advertisements in cities.

D. Names of settlements, signboards in roads, external streets, Arab city and location names.

E. Changing the names of the streets and places.

F. Hebrew media.

G. Working in Israel.

H. Direct contact with Israeli soldiers at military checkpoints/ roadblocks in the West Bank.

I. Imprisonment or detention.

J. Miscellaneous.

\subsection{The Names of Commercial Goods, Such as Food, Beverages, and The Like}

This is the first form of linguistic invasion exercised by Hebrew in the West Bank. Regardless of the economic relationship between the Israeli occupier, and the Palestinians, and regardless of the limitations of this link, any commodity arrives in Palestine has its name given by the country of origin including those from Israeli; they carry Hebrew names.

Consumer markets in the West Bank, small or large, are stuffed with goods of the same Hebrew names. Here is a list of the names of a number of these commodities (table 1).

Table1. Israeli commodities with Hebrew names in Palestinian markets

\begin{tabular}{|c|c|c|}
\hline Hebrew word & Arabic equivalent & English equivalent/interpretation \\
\hline 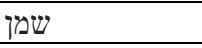 & 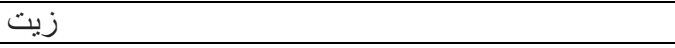 & Oil \\
\hline מרגרינה & زبدة & Butter \\
\hline 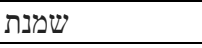 & لبن (ر ائب دسم) & Yoghurt \\
\hline תפוזינה & نوع من انواع العصائر & A type of juice \\
\hline 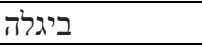 & أعو اد من الدقيق المملَح & Salted flour sticks \\
\hline 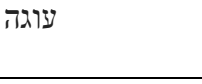 & عُكا، نوع من المعجّنات، يشبه (التصبيرة) في المملكة السعبّة العبّة & A kind of pasty (similar to tasbira in KSA) \\
\hline 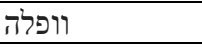 & بفلا، بسكويت محشو & Filled biscuits \\
\hline
\end{tabular}

\subsection{Transactions and Official Documents: Civil and Non-Civil}

Before the advent of the Palestinian National Authority in 1994, the so-called Israeli Civil Administration was responsible for the Palestinian civil affairs; all the transactions and official documents related to education, health, documentation, economics, civil status, and otherwise were issued by this administration and were written in Arabic and Hebrew. There were similar to bilingual dictionaries. This situation remained, in many of these matters, the same during the reign of the Palestinian National Authority, in what is known as District Coordination and Liaison.

The researchers reckon this form of invasion has barely harmed Arabic as the Palestinian citizen has always been interested in Arabic part of the document or the transaction. In other words, Hebrew does not attract their attention and it does not mean anything to them, either. Added to this is that the majority of the Palestinians could not read or write in Hebrew.

\subsection{Banners and Commercial Advertisements in Cities.}

Like all other countries, banners and commercial advertisements are usually displayed on window shops or facades of Palestinian shops, stores, streets and external roads across the West Bank. These 
banners act as prominent media outlets; they play a significant role in preserving the cultural heritage and linguistic legacy; they also enrich the people stock of vocabulary. However, some banners and ads are written using Hebrew contents and connotations.

Banners and ads are of four types in the West Bank:

a. Banners and signs written in both Arabic and Hebrew. This type is widespread in the Palestinian cities and villages which can be easily accessed by Israelis, mostly settlers; they most advertise a vehicle maintenance shops or garages that were originated by the occupier himself and were inevitable for the Palestinian.

b. Banners and signs written in Arabic letters but representing Hebrew words. The words sound strange to the language. In Nablus city, the researchers have seen the following signs:

i. متثئم لي which is equivalent to the Hebrew (מתאים לי) meaning "for me" in English.

ii. مخراز حيفا which is equivalent to (מכרז חיפה) meaning Haifa Auction

It is worth noting that this type is limited and not common due to the fact that it is invented by the Palestinians themselves.

c. Banners written in Hebrew only. This type is so rare in most cities of the West Bank because it is completely banned for the Israelis to come to these cities. However, East Jerusalem abounds with signs and banners of this type as it is possible for the Israelis to go there and shop from Arab, Palestinian stores.

d. Banners and signs written in Arabic, Hebrew and English. Again, this type is very rare and it is addressed to tourists and foreigners. East Jerusalem and Bethlehem have shops which display banners and signs of this type.

The researchers believe that, despite the fact that these types of banners manifest a kind of linguistic invasion and an attempt to replace it with Hebrew, they do not make a real threat to Arabic except in East Jerusalem. They have started to vanish all through the West Bank especially after the advent of the Palestinian National Authority in 1994.

In order to ward off what may be caused by such a pattern of linguistic invasion and to avoid any possible contamination of the Arabic, The Palestinian Authority, at least in the West Bank, is supposed to put into force a number of laws and legislations which necessitate the use of Arabic in writing the advertisements, the banners and the commercial signs. The question is: Is it possible for an Israeli citizen to write a banner, an ad, or a commercial in Arabic and Hebrew or sometimes in Arabic merely (Jabr \& Hamad, 2006)?

\subsection{Names of Settlements, Signboards in Roads, External Streets, Arab City and Location Names}

The Israelis have been establishing a lot of settlement throughout the West Bank since 1976; they have Hebrew names. The Israeli occupation has laid signboards with Arabic and Hebrew writing to lead to these settlements. Sometimes, they add English. Here is a list of names of some settlements:

Table2. Names of settlement as shown on road signboards

\begin{tabular}{|c|c|c|}
\hline Name of settlement in Hebrew & Name of settlement in Arabic & Name of settlement in English \\
\hline 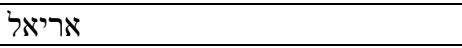 & أريئيل & Ariel \\
\hline יצהר & يتسهار & Yitzhar \\
\hline איתמר & ايتمار & Itamar \\
\hline שילה & شيلو & Shiloh \\
\hline מעלה אדומים & معاليه أودوميم & Ma'ale Adumim \\
\hline 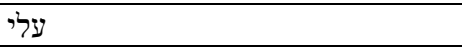 & عيلي & Eli \\
\hline אלון מורה & ألون موريه & Alon Moreh \\
\hline פסגות & بساغوت & Psagot \\
\hline שבי שומרון & شافي شومرون & Shavei Shomron \\
\hline דותן - - - - 1 & دوتان & Dotan \\
\hline קדומים & قدو ميم & Kdumim \\
\hline 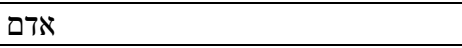 & آدم & Adam \\
\hline ברכה & بر اخا & Bracha \\
\hline
\end{tabular}


Bilingualism in the West Bank: The Impact of Hebrew on Arabic under the Israeli Occupation Since 1967

\begin{tabular}{|c|c|c|}
\hline בית אל & بيت إيل & Beit El \\
\hline קריית ארבעה & كريات أربع & Kiryat Arba \\
\hline בקעת הירדן & بكعات هيردين & Jordan Valley \\
\hline גבעת זאב & جفعات زئيف & Givat Zeev \\
\hline פסגת זאב & بسغات زئيف & Pisgat Zeev \\
\hline גוש עציון & جوش عتصيون & Josh Etzion \\
\hline מכמש & مخماس & Machmaş \\
\hline מצפה יריחו & متسفيه يريحو & Mitzpeh Jericho \\
\hline אפרת & افر ات & Efrat \\
\hline תפוח & تفوح & Tappouh \\
\hline סוסיא & سوسيا & Susya \\
\hline
\end{tabular}

A closer look at table 2 above shows that all names are written in Arabic letters but representing Hebrew words; the same is true about English equivalents except the one called Jordan Valley which is, in fact, not a settlement but a wide area including many small settlements. There is no doubt that these Hebrew names are a real threat to the Palestinian awareness as long as there is occupation.

The Israeli occupation has intentionally distorted names of certain Palestinian cities, towns and villages changing the names from Arabic to Hebrew and writing the Hebrew names in Arabic; this is crystal clear when an observer notices the road signboard scattered alongside the West Bank. For instance, the city name of Nablus is (نابلس); the road signboard reads (שכם) in Hebrew and (شخيم) in Arabic. Another example is the name of the Palestinian city of Hebron; the Arabic name is (الخليل) and the Hebrew equivalent is (هברון); the road signboard reads (هبرون) instead of (الخليل). A small village to the west of Nablus is called (Kafr Qaddoum) in English and (كفرقدّوم) in Arabic. The Hebrew name is (קדומים); the road signboard shows the Hebrew transliteration of the name, i.e. (قدوميم). Finally, there is a funny road signboard that show where a very small village to the south-east of Nablus is; the village is called (Osarin) which is equivalent to the Arabic name (أُوصَرين). However, the Israelis write using the Hebrew manifestation of the word.

Actually, there are many road signboards that display correct Arabic names for some cities and villages; however, settlers get used to crossing them out and retaining the Hebrew and English manifestations. To the researchers' belief, such a misrepresentation, or distortion is not that significant linguistically because the pure Arabic names are circulated and used by all Palestinians without exception. But, politically, "road signs are the latest front in Israel's battle to erase Arab heritage from much of the Holy Land" (Cook, 2009).

\section{E. Changing the names of the streets and places.}

There are certain cities in the West bank that the Israelis tried hard to Judaize them to obliterate their Arab, Islamic identity and give them a fake Jewish identity. The best example is the city of Jerusalem. One way of Judaizing the city is to change the names of many of its streets, alleys, and locations that used to carry Arab names, but now they have Hebrew names. The researchers contacted the Palestinian Mapping and Geographic Information Systems Department of the Arab Studies Society in Jerusalem which provided us with two lists; the first list contains the names of all the streets in the Jewish Quarter which have been changed (Table 3), and the second list contains the names of some streets in the Muslim Quarter that have been changed (Table 4).

Table3. Names of the streets/places in the Jewish Quarter which have been changed

\begin{tabular}{|c|c|c|}
\hline Ancient Arabic names & New Hebrew names in Arabic & New Hebrew names in Hebrew \\
\hline طريق النبيّ داوود & طريق حاباد & דרך חב"ד \\
\hline طريق سوق الحصر & طريق حاباد & דרך חב"ד \\
\hline طريق المناضلين & شار ع هايهو ديم & דרך היהודים \\
\hline عقبة غنيم & شار ع ها_ميتزيلتيم & רחוב המצילים \\
\hline طريق حارة الشرف & شار ع ها_كو تيل & דרך הכותל \\
\hline حوش الغز لان & شار ع ها-تاميد & רחוב התמיד \\
\hline زقاق غرناطة & شار ع ها-بيكوريم & רחוב הביקורים \\
\hline طريق الميدان & شار ع ميسجاف لداخ & רחוב מסגב לדך \\
\hline طريث أبو مدين & شار ع معالوت رابي جيتز & רחוב מעלות רבי גץ \\
\hline درج الطابون & شـار ع بلوجات هكوتيل & רחוב פלוגת הכותל \\
\hline شارع عمر بن الخطاب & شار ع باتي ماهسي & רחוב בתי מחסה \\
\hline
\end{tabular}


Table4. Names of the streets/places in the Muslim Quarter which have been changed

\begin{tabular}{|c|c|c|}
\hline Ancient Arabic names & New Hebrew names in Arabic & New Hebrew names in Hebrew \\
\hline عقبة التكية / خاصكي السلطان & المعالوت همادر اشا & מעלות המדרשה מעה מעל \\
\hline طريق الباز ار & طريق داوود & דרך דוד \\
\hline سويقة علون & طريق داوود & דרך דוד \\
\hline طريق النبي داوود & طريق حاباد & דרך חב"ד \\
\hline طريق المأذنة الحمر اء & شار ع هاتساريا هاهو ديم & רחוב חצרי היהודים \\
\hline طريق الهلال/زقاق البوس & شار ع هاسهار & רחוב הסהר \\
\hline طريق المجاهدين & شارع شعار هناريوت & רחוב שער האריות \\
\hline عقبة درويش & شار ع شعار هابر اخيم & רחוב שער הפרחים \\
\hline طريق القادسية & شار ع شعار هابر اخيم & רחוב שער הפרחים \\
\hline طريق الواد & شار ع حاجاي & רחוב הגיא \\
\hline سوق خان الزيت & شار ع بيت حاباد & רחוב בית חב"ד \\
\hline طريق باب الساهرة & شار ع بونداك هاهو ديم & רחוב פונדק היהודים \\
\hline طريق باب حطة & شار ع انطونيا & רחוב אנטוניה \\
\hline
\end{tabular}

\section{F. Hebrew media.}

Hebrew media vary just like any other media tool in the world. There is the audio represented by the Israeli Arabic Radio which is called (Call Israel). They have also a visual medium which is represented by the Israeli TV channel in Arabic. These two media types broadcast content using, in most cases, Standard Arabic as they recruit linguistically highly qualified presenters and correspondents (Khader, 2014). However, these presenters sometimes use Hebrew words and expressions. The constant use and repetition of such words is very likely to make them familiar to the Palestinians and may result in negative outcomes among them.

The commercial advertisements broadcast by these media have undoubtedly helped spread some Hebrew words among the Palestinians who incline to use them at a daily basis. There are so many products that are always promoted via these media channels; most of them are food and construction products (see table 5).

Table5. Hebrew product names promoted via Israeli media in Arabic

\begin{tabular}{|c|c|c|}
\hline Product name in Arabic & Product name in Hebrew & Description in English \\
\hline تنوفا & תנובה & Tnuva (Dairy products) \\
\hline عيليت & 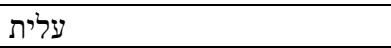 & Elite (Food products) \\
\hline أوسيم & 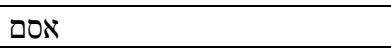 & Osem (Food products) \\
\hline شتر اوس & שטראוס & Strauss (Food products) \\
\hline عسيس & 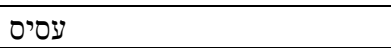 & Assis (Juice products) \\
\hline ميكوروت & מקורות & Mekorot (Water supply company) \\
\hline طمبور & טמבור & Tambour (Paint products) \\
\hline نيشر & נשר & Nesher (Cement company) \\
\hline
\end{tabular}

\section{G. Working in Israel.}

Large numbers of Palestinian workers go to Israel, Historic Palestine occupied in 1948, seeking form job in various sectors including construction, agriculture and industrial. Most of these workers use Hebrew forcibly when they get into contact with their employers or Israeli citizens. They tend to talk in Hebrew to address their bosses in the workplace. When they get home back, some of the use Hebrew intentionally while others use it unintentionally chanting in front of their families and friends some words they get accustomed to using (Amara, 2006). Table 6 shows a list of the most common Hebrew words chanted by Palestinians in the West Bank.

Table6. Common Hebrew word used by Palestinians in the West Bank

\begin{tabular}{|c|c|c|}
\hline $\begin{array}{l}\text { Hebrew word in Arabic } \\
\text { writing }\end{array}$ & Hebrew word in Hebrew writing & $\begin{array}{l}\text { English equivalent or } \\
\text { interpretation }\end{array}$ \\
\hline ل اليشكا & לשכה & Bureau (Work Office) \\
\hline عافوداه & עבודה & Work/job \\
\hline مناهيل & 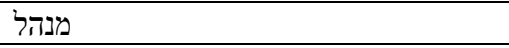 & Boss/employer \\
\hline 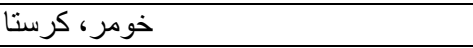 & חומר & Stuff/materials \\
\hline 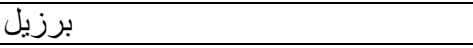 & ברזל & Iron/steel \\
\hline ميلت & מלט & Cement \\
\hline
\end{tabular}




\begin{tabular}{|c|c|c|}
\hline حول & חול & Sand \\
\hline بلوك & בלוק & Brik \\
\hline ميسميريم & מסמרים & Nails/ pins \\
\hline طوريّة & טוריה & Hoe \\
\hline طِيّاح & טייח & Bleacher / fuller \\
\hline دكت & דקט & Plywood \\
\hline بتيش & פטיש & Hammer \\
\hline أرجاز ، محال & ארגז & Box/case \\
\hline ريشت & רשת & Grid \\
\hline شايش & שיש & Marble \\
\hline تيكونيم & תיקונים & Repairs/ fixing \\
\hline بجوم & פיגום & Scaffolding \\
\hline حجِور اه & חגורה & Lintel \\
\hline منوف & מנוף & Crane/winch \\
\hline حماموت & הממות & Greenhouse \\
\hline تفتوف & טפטוף & Sprinkler/drip \\
\hline مَمطيرا & ממטרה & Sprinkler/drip \\
\hline
\end{tabular}

\section{H. Direct contact with Israeli soldiers at military checkpoints/ roadblocks in the West Bank.}

Since the 1990s, Israel has created hundreds of permanent roadblocks and checkpoints staffed by Israeli soldiers or border police (von Benda-Beckmann, 2009). Direct contact with Israeli soldiers has also a negative effect on Arabic; the Palestinians get into contact with soldiers at roadblocks and checkpoints whether they are permanent like those at the entrance of major cities, (e.g., Jerusalem and cities of the Green Line Area) or surprise flying roadblocks between cities, towns, villages and camps in the West Bank. Constant repetition of certain Hebrew words at these checkpoints makes it inevitable for the Palestinians to learn them and, consequently, use them in everyday conversations. Table 7 bellow shows the most common words.

Table7. Common military Hebrew words Palestinians learn at roadblocks

\begin{tabular}{|c|c|c|}
\hline $\begin{array}{l}\begin{array}{l}\text { Hebrew word in Arabic } \\
\text { writing }\end{array} \\
\end{array}$ & $\begin{array}{l}\begin{array}{l}\text { Hebrew word in Hebrew } \\
\text { writing }\end{array} \\
\end{array}$ & English equivalent or interpretation \\
\hline محسوم، أو مخصوم & 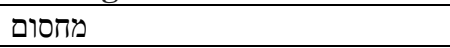 & Checkpoint/roadblock \\
\hline 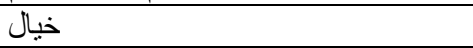 & 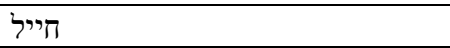 & Soldier \\
\hline مشطرا & משטרה & Police \\
\hline مشمار جِبول & משמר הגבול & Border police \\
\hline سيجر & סגר & Closure \\
\hline شو مير & שומר & Guard \\
\hline عوزي & 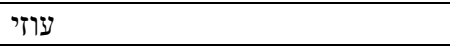 & Uzi (a kind of gun) \\
\hline بيجوع & פיגוע & Explosion \\
\hline 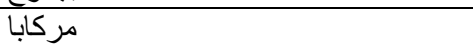 & מרכבה & Merkava (a kid of tank) \\
\hline مخشير & מכשיר & Transceiver/walkie-talkie \\
\hline
\end{tabular}

\section{Imprisonment or detention.}

Hundreds of thousands of Palestinians have been arrested or detained by the Israeli occupation. While in prisons, these Palestinians get into contact with Hebrew when are imprisoned, detained or interrogated by soldiers and intelligent service agents. Surely, they learn some words and expressions; after release, some of them start using these words (e.g., "كنتينة which is equivalent to the Hebrew word "קנטינה" meaning Canteen in English) in everyday conversations.

\section{J. Miscellaneous.}

Finally, Arabic everyday speech of the Palestinian West Bank abounds with Hebrew words that cannot be confined or grouped under a suitable heading see table 8 .

Table8. Miscellaneous words Palestinians use in everyday speech

\begin{tabular}{|l|l|l|}
\hline $\begin{array}{l}\text { Hebrew word in Arabic } \\
\text { writing }\end{array}$ & Hebrew word in Hebrew writing & English equivalent or interpretation \\
\hline الكنيست & כנסת & Knesset \\
\hline כסף & כקל & Noney \\
\hline شيكل & NIS (Israeli currency) \\
\hline
\end{tabular}




\begin{tabular}{|c|c|c|}
\hline أغورة & אגורה & Agoura (smallest unit of NIS) \\
\hline بيسح & פסח & Pessach / Passover \\
\hline حداش & חדש ( - (1) & New \\
\hline البجروت & בגרות & Matriculation/High school diploma \\
\hline لئومي، هبو عليم & לאומי & Names of Israeli Banks \\
\hline توتو، لوتو & טוטו & Loto/ Lottery \\
\hline بيزك & בזק & Bezeq (Telecommunication company) \\
\hline تحناه & תחנה - - - (- & Bus stop \\
\hline مونيت، أسكر اه & מונית & Taxi \\
\hline ت ت تؤوريا & תאוריה & Driving theory test \\
\hline ر ت امزور & רמזור & Traffic light \\
\hline 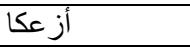 & אזעקה & Siren \\
\hline كوبات حوليم & קופת חולים & Primary care facility \\
\hline بيت عوليم & בית חולים & Hospital \\
\hline نخون & כון & (That's) right \\
\hline كين & כן & Yes/OK \\
\hline مكّابي & מכבי & Brigade/Maccabee \\
\hline سع - ( - سع & סע & Go/move/drive \\
\hline بو & בוא & Come (here) \\
\hline شلوم & שלום & Salam (peace) \\
\hline
\end{tabular}

Third: Do the Palestinians in the West Bank face the problem of linguistic dualism: Arabic and Hebrew?

Perhaps the most important factors that lead to bilateral linguistic evolution, in any country, is having multiple identities. In the dual identity atmosphere that is common among Israeli Palestinians in the Green Line Area, bilingualism among them is inevitable; most of them became fluent in Hebrew, along with their mastery of Arabic, but the status of the Arabic language has started to deteriorate gradually through generations. Arabic started to be practiced merely inside houses to address family members, at schools to read books written in Arabic, and, mainly, in places of worship because Arabic "derives its currency in historical terms from its association with Islam" Suleiman, 2004, p 40). By contrast, Hebrew has become the common language among these Palestinians; it is used in almost all aspects of their life in Israel (al-Rifa'i, 2001).

This is not the case for the West Bank residents. Standard Arabic has preserved its place and status; no linguistic duality has arisen. The Palestinians there are not obliged to learn the Hebrew language as it is not necessary to conduct their living affairs and none has forced them to use to contact with any one let be an Arab or a Jew. Likewise, the Aarb inhabitants of Jerusalem are also not obligated to master the Hebrew language. It is easy for Arabic speakers in Jerusalem to grow up and live without being proficient in Hebrew. The city is separated, sharply to parts or neighborhoods: some use Arabic and others speak Hebrew. The school system in the city consists of two networks of education: a network in Arabic, in the east of the city, while schools in the western part of the city use Hebrew.

The Arabic language is, therefore, the prevailing official language among the Palestinians in all institutions, including educational one. If it happens and one imposes Hebrew in the West Bank, just the same way in civil official documents that relate to official authorities, Arabic representations are prioritized as if one is handling an Arabic-Hebrew dictionary. As for the Hebrew words and expressions that may penetrate the Arabic language through daily direct contact with Israelis, the researchers reckon it does not pose a real threat to the language and it is not a case of bilingualism, either.

Whatever the matter, the linguistic reality prevailing in the West Bank does not relate to duality; one barely finds a Palestinian who master Hebrew, in speech and writing, the way s/he does with Arabic. However, very few Palestinian academicians use Hebrew as native speakers. In short, the Palestinians do not face language duality.

\section{Fourth: Is there any linguistic normalization? If yes, do the Palestinians tend to resist it or manifest linguistic tolerance?}

In the article "Israel's Exceptionalism: Normalizing the Abnormal" (2011) the term normalization, from a pure Palestinian perspective, is defined as "he participation in any project, initiative or activity, in Palestine or internationally, that aims (implicitly or explicitly) to bring together Palestinians (and/or 
Arabs) and Israelis (people or institutions) without placing as its goal resistance to and exposure of the Israeli occupation and all forms of discrimination and oppression against the Palestinian people" (para. 5). The concept has become widespread in various media not only locally or globally but also internationally.

Based on the previous definition of the term, and for the sake of the current study, the researchers are interested in cultural normalization rather than any other form of normalization. The study seeks to find out whether there are cultural activities or initiatives between the Palestinians and the Israelis that reach the level of linguistic normalization or even tolerance towards the process or not.

Officially, it is crystal clear that there is no such inclination to this type of normalization, at least by the Palestinians in the West Bank; they have not built a serious cultural connection or relation with the Israelis that can be considered as cultural or linguistic normalization. In typical situations, normalization usually begins by constructing real, mutual cultural relationships such as establishing scientific centers and academies, exchanging academic experience and university professors and instructors, mutual visits and exchange of scholars, thinkers and artists, holding conferences and scientific gatherings or forums, mutual collaboration among media agencies, formulating unified school curricula, and many others that may help settle peace and promote the Jewish culture, including, of course, Hebrew, among Palestinians of the West Bank.

"Israel has exercised political rule over the Palestinians for about 67 years, a time period sufficient for bilingualism to develop" in the Green Line Area rather than in the West Bank (Abu Elhija, 2017). In spite of the need for a coercive, compelling link with the Israeli occupier, as the sovereign entity that controls all matters, there has been no connection between Palestinians in the West Bank and the Israelis through any of the previously mentioned areas. Even if such connection exists, then there must be visible pointers (e.g., constructing facilities and centers to initiate and implement cultural normalization) on the ground. Furthermore, it becomes necessary for the Palestinian to learn Hebrew and to strive to master it. Again, this calls for the centers to be established and for the courses to be held to teach the Hebrew language in the West bank.

\section{Fifth: Is the Hebrew language considered a spoil of occupation, or does it reveal a defect, which might threaten the Arabic language?}

Linguists reckon it is plausible enough for languages to connect and influence each other due to direct contact among their users; they also believe that this connection should not result in one language obliterating the other or even replacing it altogether (al-Saran, 1963).

There has been a contact between Arabic and Hebrew in the West Bank due to direct contact among the two peoples for their own interests and goals. Hebrew could not replace Arabic or be a second language for the Palestinians in the West Bank; it will never. However, there are minor traces of negative Hebrew interference on Arabic. On the one hand, the occupier tries to uproot the Arabic and distort the Arabic linguistic structure via inserting some Hebrew aspects; On the other hand, such a contact may result in bilingualism, mostly at the level of spoken language, among the Palestinians of the West bank just like what happened with the Palestinians of Israel. Both may result in weakening Arabic among future generations (Mari, 2003).

No one can deny the effects of such an extraneous, intrinsic effect of Hebrew based on the norms of the linguists; whatever Hebrew aspects get into Arabic or have leaked unintentionally into it should be regarded as extraneous or strange because, in the customs of linguists, chiefly language academies, a new word in a language is seen as a linguistic intrusion if it does not have an equivalent the target language. Most of the leaked Hebrew items do have equivalents. Perhaps this has been facilitated by fact that Arabic and Hebrew are two Semitic languages. Therefore, there is a lot of convergence and similarity between them in ways. Most of this leak appears in the Hebrew vocabulary, which has started to, unintentionally, run on the tongues of the people in their everyday speech.

\section{CONClusion}

The Arabic language is distinct enough having a glorious past, and a noble linguistic legacy and heritage; it reflects a high-quality thought and represent an ancient civilization; therefore, it has been always capable of standing still in the face of successive waves of pollution, alienation, language invasion or conquest through the successive colonial waves, among which was, and still is the Israeli occupation Israel of the West Bank. 
The occupation has sought, exerting various efforts and using different types of techniques, to undermine everything related to the Palestinian Arab identity in the West Bank; it has also tried to damage and negatively influence the Arabic language. The current study is centered around these two main questions: What is the reality of this language, and did Hebrew have an impact on it?

The study results show that he Arabic language, in the West Bank of Palestine, has faced a lot of threats and has been subjected to various negative influences, among which is Hebrew, the language of the occupier. The impact of Hebrew on Arabic is considered as a linguistic invasion which is clearly manifested though the intrusion of words and expressions in some commercial and economic products, official documents, commercial banners and ads, road signs, names of settlements, road and places that get into Arabic via Hebrew mass media, working inside Israel, direct contact with soldiers at roadblocks and checkpoints as well as in prison during detention or imprisonment. This invasion has been constantly encountered by a lot of national Palestinian institutions to protect it and preserve the Glory of this cultural asset. The most influential institution is the Palestinian Ministry of Education and Higher in addition to mass media.

The researchers find that the average Palestinian citizen, being despised and humiliated by the nasty Israeli occupation, does not suffer from the problem of bilingualism; s/he is not required to learn and master the Hebrew language to manage his/her affairs. The Palestinians of the West Bank have not been forced to get into contact with the Israeli occupier in a way that entails learning its language, i.e. Hebrew and mastering it. Despite the coercive link between the Palestinian and the Israeli occupation, no single manifestation of cultural or linguistic liaison, relationship, or normalization has been detected between the Palestinians of the West Bank and the Israelis which might promote Hebrew and spread it so that it become a second language.

Finally, it is crystal clear that there Hebrew has impacted Arabic negatively when Hebrew words leaked to Arabic. This leakage is a matter of intrusion because of the existing equivalents in Arabic; it is also limited and will not result in a deterioration of Arabic nor a replacement by Hebrew.

\section{REFERENCES}

[1] Abu-Al-rob, Hassan. (2011). 'Teaching Arabic in Jewish Schools in Israel: Preparatory School Curriculum as a model'. Journal of Al-Quds Open University for Humanities and Social Sciences, 22: 325359.

[2] Abu Elhija, Duaa. (2017). 'Hebrew Loanwords in the Palestinian Israeli Variety of Arabic (Facebook Data). Journal of Language Contact, 10(3): 422-449.

[3] Al-Rifai, Jamal. (2001). 'The Crisis of the Arabic Language in Israel: Influences of Hebrew on the language of the Palestinian press in Israel'. Journal of Eastern Studies, 40:199-234.

[4] Al-Saran, Mahmoud. (1963). Language and Society: An Attitude and a Discipline. Egypt: Alexandria publisher.

[5] Amara, Amara. (2013). Arabic Language in Israel: Vision and Challenges. Jordan: Dar Alkikr

[6] Amara, Amara. (2006). 'The Vitality of the Arabic Language in Israel from a Sociolinguistic Perspective'. Adalah's Newsletter, The legal center for Arab minority rights in Israel, 29: 1-10.

[7] Bayt al-Maqdis Academy of the Arabic Language (n.d.). Dictionary of Uprising Glossary. Unpublished Dictionary manuscript.

[8] Cook, Jonathan (2009, 17 July). Israeli Road Signs. Retrieved from https://www.counterpunch.org/2009/ 07/17/israeli-road-signs/

[9] Harel-Schlef, Ayelet. (2005). 'Arabic as a minority language in Israel from a comparative point of view'. Adalah online magazine, 14: 1-12.

[10] Israel's Exceptionalism: Normalizing the Abnormal. (2011 October, 31). The Palestinian Campaign for the Academic and Cultural Boycott. Retrieved from http://www.pacbi.org/etemplate.php?id=1749

[11] Jabr, Yahya \& Abeer Hamad. (2009). 'Between Arabic and Hebrew'. An-Najah University Journal for Research: Humanities, 1: 21-33

[12] Jabr, Yahya. (1990). 'The Reality of Languages in Palestine'. Al-Bayder Tunisia, 2:17-38.

[13] Kayyal, Mahmoud. (2008). Interference of the Hebrew Language in Translations from Modern Hebrew Literature into Arabic. In: Daniel Simeoni, Anthony Pym and Miriam Shlesinger (eds), Beyond Descriptive Translation Studies, Investigations in Homage to Gideon Toury, Amsterdam/Philadelphia: John Benjamins, pp. 33-50.

[14] Khader, Fathi. (2014). Retreat of Linguistic Performance in the Arab Mass Media. Al Mishkat Journal for Humanities and Social Sciences Studies, 1(2):1-49. 
[15] Khoury, Naseem. (2005). The Collapse of Linguistic powers. Beirut: Center for Arab Unity Studies.

[16] Koplewitz, Immanuel. (1990). 'The Use and Integration of Hebrew Lexemes in Israeli Spoken Arabic'. In: Durk Gorter, Jarich F. Hoekstra, Lammert G. Jansma, \& Jehannes Ytsma (Eds.), Fourth International Conference on Minority Languages, Clevedon, UK: Multilingual Matters, vol. 2, pp. 181-195.

[17] Mari, Abdulrahman. (2003). The Impact of Hebrew on Arabic. Al-Risallah, 11:129-156.

[18] Mubarak, Mazen. (1979). Towards a Linguistic Awareness. Beirut: Ar-Resalah Publishers.

[19] Muchnikm, Malka, Marina Niznik, Anbessa Teferra, Tania Gluzman. (2016). Elective Language Study and Policy in Israel, (1st ed.). London: Palgrave Macmillan

[20] Nashef, Ismail. (2018). The Arabic Language in the Zionist Regime: The Story of a Colonial Mask. Qatar: Arab Center for Research \& Policy Studies.

[21] Odeh, Khalil. (2005). 'The negative impacts of Israeli occupation on the future of Arabic in Palestine'. An-Najah University Journal for Research: Humanities, 2: 1-11

[22] Spolsky, Bernard \& Elana G. Shohamy. (1999). The Languages of Israel: Policy, Ideology, and Practice. United Kingdom: Multilingual Matters.

[23] Stabback, Philip. (2016). What Makes a Quality Curriculum. In-Progress Reflections on Current and Critical Issues in the Curriculum and Learning. UNESCO International Bureau of Education. http://unes doc.unesco.org/images/0024/002439/243975e.pdf

[24] Suleiman, Yasser. (2004). A War of Words: Language and conflict in the Middle East. Cambridge: Camb ridge University Press.

[25] Talmon, Rafael. (2000). 'Arabic as a Minority Language in Israel', in: Jonathan. Owens (ed.), Arabic as a Minority Language. Berlin and New York: Mouton de Gruyter, pp: 199-220.

[26] Von Benda-Beckmann, Franz; Keebet von Benda-Beckmann and Julia Eckert. (2009). Rules of Law and Laws of Ruling: On the Governance of Law. Farnham, UK: Ashgate.

[27] Zidan, Ruqqayyah. (2010). The Impact of Hebrew on Yammah Dialect, Language reality in Palestine, An-Najah National University, 20 January, 2010 Al-Quds Newspaper.

\section{AUTHORS' BIOGRAPHY}

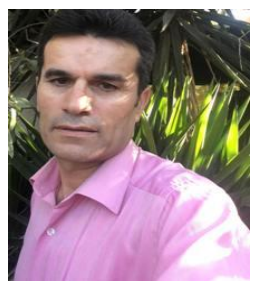

Dr Oqab Jabali, was the director of the Language Center and is now instructor of English in the Department of English at An-Najah National University, Nablus, Palestine. Besides teaching, writing, translation and linguistic courses, he is a freelance translator and he teaches English for specific purpose in the language center. He holds a PhD in Cultural Studies and Political Sciences from the Jagiellonian University in Krakow, Poland, a Master's degree in Translation and Applied Linguistics, and a High Diploma in English teaching Methods. His major publications include writing, translation and linguistic studies, (medical) education and women studies.

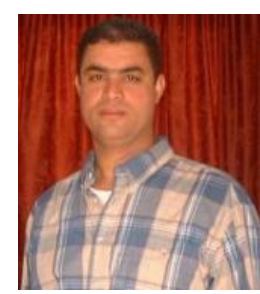

Dr Abed Alkarim Ayyoub, was the Chair of the Teaching Methods Department at the Faculty of Education and is now faculty members in the Department of Social Sciences at the English at the Faculty of Economics and Social Sciences, An-Najah National University, Nablus, Palestine. Besides teaching different courses, he is a professional statistician who analyze all types of data statistically. He holds a PhD in Measurement and Evaluation from Yarmouk University in Irbid, Jordan, a Master's degree in Education, and a bachelor degree in Applied Sciences. His major publications include education, statistics, teacher training, and social sciences studies.

Citation: Oqab Jabali, Abed Alkarim Ayyoub. "Bilingualism in the West Bank: The Impact of Hebrew on Arabic under the Israeli Occupation Since 1967" International Journal of Humanities Social Sciences and Education (IJHSSE), vol 8, no. 9, 2021, pp. 109-120. doi: https://doi.org/10.20431/2349-0381.0809011.

Copyright: () 2021 Authors. This is an open-access article distributed under the terms of the Creative Commons Attribution License, which permits unrestricted use, distribution, and reproduction in any medium, provided the original author and source are credited. 